\title{
Chapter 5 \\ Urban Cosmopolitanisms in the Arab \\ World: Contributing to Theoretical \\ Debates from the Middle East
}

\author{
Franck Mermier
}

\subsection{Introduction}

A positive re-evaluation of the idea of cosmopolitanism has taken place in recent years, particularly in the field of anthropology. As Michel Agier has shown in La Condition cosmopolite (2013), cosmopolitanism is a way of revising notions of identity and national borders. Yet the shared experience of the "cosmopolitan condition as the fact of living in the here and now (locally), but with an imagined wider world as both the condition of that life and a way beyond it" (97) described by Agier is no longer restricted to a small, internationally mobile elite associated with globalization. Pnina Werbner supports this assertion when stating that a vernacular, historically and spatially situated version of cosmopolitanism must be put at the core of anthropology. In her view, cosmopolitan spaces "are trans-ethnic, collectively emergent 'worlds,' shared discourses that transcend cultural boundaries and parochial lifestyles. According to this definition, a cosmopolitan is a person who actively belongs to, participates in and contributes to the creation of such trans-ethnic cultural and ideological worlds" $(2008,50){ }^{1}$

City-based cosmopolitanism has other connotations related to the ethnic, religious or cultural diversity of the urban environment. Whether considered diachronically or synchronically, this type of cosmopolitanism has existed in various forms, covering communities that are open or segregated from one another to a greater or lesser extent. These various forms of urban cosmopolitanism are often seen as determining or altering the urban character of the cities concerned, functioning as a differentiating factor.

\footnotetext{
${ }^{1}$ See also her introduction to that volume.

F. Mermier $(\bowtie)$

CNRS IRIS, Ecole des Hautes Etudes en Sciences Sociales, Paris, France

(C) The Author(s) 2021

C. Lejeune et al. (eds.), Migration, Urbanity and Cosmopolitanism in a

Globalized World, IMISCOE Research Series,

https://doi.org/10.1007/978-3-030-67365-9_5
} 
This chapter is situated in a broader discussion on cosmopolitanism and cities in the Arab Middle East. It echoes the recent scientific interest for cities in the Arab world which reflects the urban turn that has taken place in anthropology and the social sciences in general. The urban turn has had extremely positive effects by bringing fruitful comparisons within the Arab world and across regions, leading to new perspectives for the study of cosmopolitanism. Cities in the Arab Middle East form an interurban constellation of contrasting contexts. They are interconnected and complementary. Looking into urban settings in the Arab world leads to various sociological, anthropological, and geographic questions: what are the concrete forms of social identification in Arab cities? How do social interactions unfold in such contexts? How are gender, class or ethnic relations shaped in urban environments? As the combined relevance of social roles and spaces translate into different modes across contexts, this chapter will particularly focus on the case of Aden (Yemen) under British occupation. If much has been written on the cosmopolitanism of Mediterranean cities, few analytic endeavours have been undertaken to study the urban cosmopolitanism in the pre-oil era Arabian Peninsula (Fuccaro 2009). The case of Aden is particularly well-suited to highlighting an example of segregated cosmopolitanism which engendered a new urban identity based upon exclusive citizenship. This has led to violent struggles in and for the city between rival political groups. Aden also exemplifies the power of nostalgia through the selective remembrance of an idealized cosmopolitanism.

\subsection{The End of Colonial Cosmopolitanism}

For Arab cities, marketplaces have often been seen as public spaces par excellence by exhibiting forms of ethnic and religious diversity that are held together by commerce (Mermier 2011). The figure of the merchant as a nodal point in networks of urban space is also familiar from the cosmopolitanism of Mediterranean cities during the Ottoman era. ${ }^{2}$ Much research, mostly marked by a nostalgia for a period believed to have been a model of community co-existence, has been carried out on these spaces. Such city cosmopolitanism has been described as

a complex urban system open to universal values and the outside world and bringing together different communities that were termed ethnicities, peoples, or nations, according to the places concerned and the vocabulary of the time. The cosmopolitan city offers a variegated social and cultural landscape, which entails a way of living the city and of living in the city. (Escallier 2003)

The inhabitants of the Near East were supposed to embody this condition of "urban cosmopolitanism" thanks to their remarkable adaptive capacity.

\footnotetext{
${ }^{2}$ For criticisms of this idea and of seeing entire cities in terms of cosmopolitanism, when strictly speaking the term should only apply to individuals, see Gekas 2009, 104.
} 
Today, this "Mediterranean of cities" has disappeared as a result of the growth of nation-states and nationalism, the marginalization of former urban elites, and the movement of rural populations to cities. In the eastern Mediterranean, this was a form of life most often associated with the countries of the Levant, including not only Lebanon and Syria but also Jordan, Palestine, parts of Turkey, and, for some, certain cities like Alexandria and Smyrna (Mansel 2010). This "Levantine society" only finally disappeared with the outbreak of the Lebanese Civil War in 1975, which Robert Ilbert called "the end of an urban order" (1991). Writing of Alexandria's cosmopolitanism at this time, Ilbert adds that the "coexistence of communities having different languages, cultures and religions living in the same space" $(1992,171)$ contributed to a "community of interest imposed by a Levantine bourgeoisie of fluid national links underpinned by a communitarian system that reserved the most important place to notables" $(1992,185)$.

The anthropologist Jean Métral employed this idea of "urban order" in an article on public space in the cities of the Levant, particularly Aleppo and Beirut, in order to identify three types of cities that could be seen to characterize the period between the early nineteenth century and the end of the Second World War. These cities included Mediterranean ports such as Istanbul, Thessaloniki, Smyrna, Beirut and Alexandria "in which there flourished a particular form of cosmopolitanism"; cities of the interior such as Ankara, Aleppo, Damascus and Cairo "where nationalism grew and was consolidated"; and, finally, desert trading centres that served as the "home of tribal patrimonialism" $(1995,263)$. The cosmopolitanism of the port cities was rooted in a form of urban life that depended on community belonging, but this did not mean that any one community dominated others. It was a cosmopolitanism based on exchange, a shared urban culture and belonging, and centered on the souq, the public space par excellence of the city.

For Sami Zubaida, cosmopolitanism is not so much a matter of cultures and nationalities mixing (as often happens in big cities) but instead certain ways of living and thinking. As Zubaida puts it, such styles of life are "deracinated from communities and cultures of origin, from conventional living, from family and home-centredness, and have developed into a culturally promiscuous life, drawing on diverse ideas, traditions and innovations" (1999, 15-16).

The idea of cosmopolitanism as a mosaic of communities living side by side can once again be traced back to the traditional elitist model of communities led by notables. It plays down the forms of exclusion that may have contributed to the growth of nationalistic feeling or the outbreak of civil war, as took place in Lebanon between 1975 and 1990, even if it could be argued in the case of Beirut that the civil war that incontestably reduced the presence of foreign communities in the city pushed Lebanon as a whole "into the avant-garde of a new wave of globalization ... As a result, Lebanon paradoxically emerged from the civil war with a notably efficient networked economy that was connected to the 'global village' that the world economy had in the meantime become" (Corm 1998, 16-17).

Zubaida rightly remarks that nostalgia for this type of cosmopolitanism fails to link it with the European imperialism of the time and the forms of segregation that prevented the "natives" from going into certain social spaces $(1999,26)$. However, 
two cities of the interior, Aleppo and Cairo, experienced significant forms of cosmopolitanism at this time. Though partially characterized by the presence of Europeans, both cities also saw the coexistence of other communities from the region. The Syrian-Lebanese community in Cairo, for example, or the Turkmens and Kurds in Aleppo, still make up a significant proportion of the populations of these cities. What was until recently the mixed composition of the population in Baghdad is another case in point (see Bader 2014).

Yet the idea of an "oriental cosmopolitanism" linked to the ports of the Levant is too narrow to be used analytically except as a way of fleshing out the familiar idea of Mediterranean cities as exhibiting values of openness and tolerance that were opposed to nationalist attempts at closure. This stereotypical opposition between city and nation holds, even today, a strong ideological charge.

Questions have been raised regarding the extent to which social practices in these cities conformed to this conceptually problematic notion of cosmopolitanism. Henk Driessen, for example, has rightly pointed out that the idea of cosmopolitanism has been used to describe a huge variety of historical situations from ancient Greece to today's post-modern "multicultural" metropolises. At the very least, he says, the use of the idea as an anthropological concept runs up against certain epistemological obstacles, its ambiguity coming from the attempt to "reconcile difference with equality and universal with pluralism" (Driessen 2005, 137). Cosmopolitanism has also had a close relationship with power, having been used at different times by various elites to entrench their cultural domination. It has existed in different forms in different historical epochs, closely associated with the notion of tolerance, with all the ambiguities that this implies (Driessen 2005).

Will Hanley, a historian of Alexandria, has also drawn attention to the fact that research on the cosmopolitanism of the "Middle East" has in general been reluctant to draw on theoretical work. As a result, he writes in an incisive article (2008), research on cosmopolitanism has just as often been used to obscure reality as to illuminate it, having the effect of hiding reality behind a thick cloak of nostalgia. The recognition that cosmopolitanism comes in many forms as well as taking into account popular cosmopolitan practices would, Hanley continues, allow much of the research carried out in this "cultural area" to rid itself of the elitist prism through which reality is often viewed and strip away obsessions with identity. The historian Edhem Eldem has also made a convincing case for seeing the Ottoman cosmopolitanism that developed from the second half of the nineteenth century onwards as a sort of Levantine cosmopolitanism. This was above all a form of "social praxis" characterized by the spread of a particular French cultural model into certain districts of Istanbul and by a particular capacity to move between different social and cultural worlds (Eldem 2013).

The upshot of such considerations is that ethnic, religious and linguistic diversity are not sufficient for labelling the cosmopolitan character of a city without taking into consideration how diversity is constituted and experienced. The big cities of the Arabian Peninsula today, characterized as they are by pronounced ethnic and spatial segregation, should not be seen in the same way as the port cities of the Mediterranean during the Ottoman period or twenty-first century Beirut or Cairo. 
The cosmopolitanism seen in Manama in Bahrain, for example, is built on a spatial segregation that applies to all the communities in the city, whether native or foreign, and is a model that characterizes all the cities of the Gulf (Gardner 2010). The type of cosmopolitanism that characterizes the Gulf, in fact, is a version of the "communitarian cosmopolitanism" identified by Francesca Trivellato in her study of community relations in sixteenth-century Livorno (2009). ${ }^{3}$ The cosmopolitan of contemporary Gulf cities emphasizes segregation because, having been built on a system of ethnic stratification based on nationality, it intends to maintain the superior status of "nationals" over immigrants.

However, ethnic stratification has had different characteristics in different societies, these being a function as much of the individual history of the society concerned as of the methods used to "manage" difference and openness to globalization. The position of each city in the region to which it belongs is also important - the Gulf cities, for example, are part of regional circulation systems like the Arabian Peninsula and the wider Arab world. This regional positioning affects social spaces and forms of sociability as well as professional, cultural and leisure activities in different ways, which means that these cities are part of a larger inter-urban space where local differences support and complement each other.

Moreover, the nostalgia for colonial cosmopolitanism can also serve to reinforce pretensions of cultural superiority when the loss of the political status of a city in a larger national unit has led to political or economic marginalization. This has been the case in Yemen, where Aden has lost out to the capital, Sanaa. The memory of the Antonin Besse family, forced to leave South Yemen after the nationalizations in 1969, is still alive today among Aden's intellectual elite, for example. This elite has reacted to the marginalization of Aden by mourning the loss of its former cultural and political dynamism, which was paradoxically linked to the British occupation. By contrast, the nostalgia felt by some residents of Alexandria for the cosmopolitan vestiges of the past does not have the same political content; instead, it is kept alive by rivalry with Cairo, where the country's political power and cultural institutions are located. The intellectuals around the magazine Amkina (Places) in Alexandria are far removed from their Aden counterparts, who gather around the newspapers Al-Ayyam and Aden al-Ghad. While they may not have heard of one another, these intellectuals are linked by a shared desire to rehabilitate a cosmopolitan past. This is all the more attractive in the case of Aden as a way of fighting against the marginalization of the city and its former elite.

\footnotetext{
${ }^{3}$ There are various types of "communitarian cosmopolitanism" that can be used to describe different forms of multiculturalism. For an example of the notion in the context of a Mediterranean city, see Trivellato 2009. For a political science definition from contemporary Europe, see Bellamy and Castiglione 1998.
} 


\subsection{Aden: Colonial Cosmopolitanism}

Aden under British rule (1839-1967) represented a singular version of a colonial "communitarian cosmopolitan" that differed immensely from all the other cities of today's Yemen. The birth of a new urban society was thus directly linked to the colonial presence and functions of the British in the city, which reconfigured the relationships with the local and far-away environment. A cosmopolitan city, Aden became a bridge between Arabia, Europe, Africa, and Asia, reproducing in its spatial configurations and its division of labor the social and ethnic hierarchies of the British Empire and mercantile capitalism.

While mosques, churches, synagogues, and Hindu and Parsi temples showcased the main faiths of its inhabitants, different rites and different ethnic and cultural identities were superimposed on these religious divisions. The descendants of several hundred Muslim residents of Aden in 1839 progressively mixed with the families of immigrants coming from North Yemen and the southern protectorates, as well as Indian Muslims, to form the social group of Aden residents. ${ }^{4}$ A separate category emerged in the heart of the population that was differentiated from Yemenis from the North and Arabs from the sultanates under British protection.

The British colonial project to install in Aden a coal depot and a military post on the maritime route to India, as well as the opening of the Suez Canal in 1869, led to a rapid development of the city's economy. Aden's maritime traffic increased so that by 1958 its port was the second-most heavily utilized in the world, after New York (Stookey 1982). After 1960, Aden replaced Cyprus as the military headquarters of the British command in the Middle East, which led to a major increase in the number of military officers and their families. During the British period, the city was almost better connected with the rest of the world than with the rest of Yemen not only because of its developed economy but also its extra-territorial political status.

Aden was placed under the direct control of the Government of Bombay before becoming, in 1937, a Crown colony. The rest of the territory of south Yemen was divided into two protectorates, that of the east, containing the sultanates of Hadhramaut and Wahidi, and that of the west, containing the regions of Yafi, Awlawi, and Radfan. The British powers decided to progressively introduce a dose of "homerule" or local representation in the government, even going so far as to organize elections in December 1955 for the legislative council. In September 1962, while a military coup put an end to the regime of the Imam of Sanaa, Aden joined the Federation of the Arab Emirates of the South which brought together 15 small states (excepting Hadhramaut).

Modern educational institutions, associations, cultural clubs, unions and political parties were created in Aden during the colonial period. An independent Arabiclanguage press emerged. At the same time, the influence of British culture profoundly marked Aden's elites. In the 1950s, Aden was also strongly influenced

${ }^{4}$ In 1839 the city had only 1289 inhabitants - 617 Arabs, 574 Jews, 63 Somalis, and 35 Indians. See Gavin 1975, 445. 
by Indian culture, not only when it came to music and fashion but also language. The different categories of Aden society, hailing from old trading families to employees or migrants from the southern part of North Yemen, all shared a negative perception of the rest of Yemen as they developed a strong feeling of belonging in the city proper (Lackner 1985, 20).

The British colonial order thus gave rise to a gradual ethnic status system that reproduced the regional and ethnic divisions of the professional world. Europeans were at the top of the hierarchy, followed by Indians, Jews, Arabs, and Somalis even if the Arabs saw themselves after the Europeans and put Muslim Indians ahead of Jews, Hindus and Somalis (Bujra 1971, 196-7). The stratification of group status that characterized Yemeni society, with its regional variations, was reinforced by the ethnic hierarchy unique to a colonial society. ${ }^{5}$ This led to new categorizations, like Aden residents themselves who were differentiated based on this two-pronged ladder of status (see Dahlgren 2010, 76-8).

Aden's ancient colonial cosmopolitanism has become fictionalized in the works of several contemporary Yemeni writers. The novels of Ali Al-Muqri (2014) and Ahmad Zayn (2015) embed their novelistic texture within a specific place, Aden, a city rendered through multiple intersecting story lines. These works express a certain nostalgia for the city's colonial cosmopolitanism, modernity, and openness. These two authors recreate, through fiction, another historical story where the colonizer and the colonized did not so much oppose each other but instead interpenetrated each other - so the deadly combats of the different nationalist movements reach their end point through the suppression of a cosmopolitan polyphony that these novels aim to rediscover.

\subsection{The Cosmopolitan Capital: Forms of Social and Urban Differentiation}

Drawing on criticisms of how the darker sides of violence, exclusion and social hierarchy are left out of the nostalgic vision of a cosmopolitan past, Diane Singerman and Paul Amar have identified various types of cosmopolitanism in contemporary Cairo $(2006,30)$. These range from nostalgia for a former multiculturalism and particular understanding of the city's heritage to the model represented today by the cities of the Gulf, though understood in specifically Egyptian terms. While Singerman and Amar admit that cosmopolitanism has often been the prisoner of transnational, normative, universalist or imperialist discourses, they argue that it can

\footnotetext{
${ }^{5}$ The traditional social hierarchy in Yemen, with its regional variations, was composed of status groups graded in the hierarchical system according to certain criteria, the most important of which are ancestry $(a s l)$ and professional activity. The descendants of the Prophet took their place at the top of the hierarchy. The other status groups were tribesmen, city dwellers of tribal origin, and at the bottom of the social order were those without tribal origin who held occupations considered dirty or vile. See Mermier 2001, 276-7.
} 
carry an alternative, liberating ethic that is far removed from narrow conceptions of nationalism or identity politics when critically employed (4). However, any illuminating value that the term has does not appear to be much advanced by extending the concept, in the shape of "cosmopolitanism from below," to a whole collection of heterogeneous practices associated with very different groups and actors on the grounds that all these seem to contest dominant nationalist narratives from vantage points in separate public spheres.

Examples chosen to illustrate this notion of cosmopolitanism go from the emergence of a new understanding of regional identity among returnees from the Arabian Peninsula living in Upper Egypt to activities to help preserve the heritage of Egypt's historic city-centres and rehabilitate the architecture of the nineteenth and twentieth centuries. They also include contemporary Nubian cultural practices, Sufi pilgrimages, and new forms of popular music. As a result, the concept of "cosmopolitanism from below" appears too much like an ideological attempt to rescue popular practices - it is hard to be entirely free from the suspicion that its proponents have been carried away by their own rhetoric. In the context of Cairo, Asef Bayat proposes the notion of "everyday cosmopolitanism," which means "the idea and practice of transcending self - at the various levels of individual, family, tribe, religion, ethnicity, community, and nation - to associate with agonistic others in everyday life" (2010, 187). However, this concept's scope seems to be restricted to the inter-sectarian relationship between Copts and Muslims and praising the role of the modern city which "severely undermines the traditional pattern of immediate, local, interpersonal, and territorial ethno-religious communities" (2010).

Mark Allen Peterson separates himself from these conceptions of cosmopolitanism in his study of cosmopolitanism in Cairo when writing of

\footnotetext{
those practices, especially the practices of consumption, through which the Egyptian upper classes and those with upwardly mobile aspirations construct themselves as transnational elites whose unequal control over Egypt's economic and political resources is justified by their modernity, and whose modernity is in turn revealed by their cosmopolitanism: their Western educations, their easy movement across transnational borders, their consumption of transnational goods, and the general display of tastes in music, literature, film, clothing, and technologies that distinguishes them from the masses. (2011,23)
}

"Cosmopolitan capital" thus becomes an important marker of class differentiation for the urban elite, particularly in Cairo, and perhaps even the most important one as it consists of "forms of cultural capital that are marked by familiarity with and mastery of globally dominant cultural codes" (de Koning 2009, 9). This system of class differentiation includes the use of English and of a dialect of Arabic sprinkled with English, a Western education, the mixing of the sexes, certain styles of clothing and forms of consumption and leisure, and the choice of places to live and socialize. These things function as social and cultural markers for a section of Cairo's upper classes, distinguishing them from places and practices considered to be popular. The latter include the theatres and cinemas of the downtown area once associated with the upper classes but today belonging to young people from the popular classes (Singerman and Amar 2006, 32). 
The spatial and social segregation of Cairo today is in large part linked to the political and economic choices that were made during the watershed of the so-called Infitah (opening) in the Sadat period (see Vignal and Denis 2006). However, in reality, this segregation also owes much to the existing class system. Cairo-style cosmopolitanism does not look far beyond the national context, including a strong element of Egyptianess that is obliged to rub along as best it can with transnational dimensions of identity (Peterson 2011, 13). In fact, these transnational identities only take on a meaning in relation to "particular worlds and places" and the (hierarchical) relations that structure them (Friedman and Rabau 2000, 200). What this local Cairo version of "consumerist cosmopolitanism" most reveals, if it were thought necessary to point this out, is that the spread of "consumerist cosmopolitanism" on a global scale requires less the homogenization of tastes and practices than an ongoing and hierarchical reconfiguration of these by local strategies of distinction (Calhoun 2002, 105).

\subsection{Cosmopolitanism Beyond Arab Cities}

From particular forms of sociability located in particular times and places to urban imaginaries, each form of city living is unique because each manifests ways of living and forms of social relationships that relate to particular and transitory social spaces. ${ }^{6}$ In a particularly illuminating article, Henri Lefebvre and Catherine Régulier have set out further perspectives suggesting ways forward for research on urban living: "the idea and the reality of the separation public/private are not the same everywhere. More specifically, there are not the same things which are hidden, shown, or which we are going to see outside" (Lefebvre and Régulier 1986, 10).

In the Arab world, the city often acts as a cultural reference point, carrying with it a whole set of values and representations linked to social position and struggles for social status in different societies. Whereas Lyn Lofland found that spatial ordering replaced "appearential" ordering in Western urban contexts, it seems that both forms of social identification coexist and intersect in Arab cities (1973, 27). The city, a disputed space, even a space for conquest, as well as a geopolitical space, may thus seem to be caught in the crossfire between, on the one hand, the domination of particular communities and, on the other, the individual or collective fault lines that aim to subvert them. Perhaps in the final analysis it is this dialectical relationship between the public and the private (the personal and the social) that lies at the root of urban life and determines both its cultural specificities and universalist dimensions. This tension, felt to a greater or a lesser extent depending on the individual city, is a cultural factor that has a different weight depending on the society concerned. However, it determines, though necessarily in different ways, the uses

\footnotetext{
${ }^{6}$ See the conception of social space developed by Henri Lefebvre in La production de l'espace (2000).
} 
that are made of public space, the forms of anonymity and sociability that can be observed, and the various forms of cosmopolitanism, including "discrepant cosmopolitanism," in each Arab city.

\section{References}

Agier, M. (2013). La Condition cosmopolite. L'anthropologie à l'épreuve du piège identitaire. Paris, La Découverte.

Al-Muqri, A. (2014). Bukhûr Adanî. Beirut: Dar Al-Saqi.

Bader, A. (2014, July 20-21). Adieu Bagdad la cosmopolite! Le Monde, p. 16.

Bayat, A. (2010). Life as politics: How ordinary people change the Middle East. Stanford: Stanford University Press.

Bellamy, R., \& Castiglione, D. (1998). Between cosmopolis and community: Three models of rights and democracy within the European Union. In D. Archibugi, D. Held, \& M. Köhler (Eds.), Reimagining political community (pp. 152-178). Oxford: Polity Press.

Bujra, A. (1971). The politics of stratification: A study of political change in a south Arabian town. Oxford: Clarendon Press.

Calhoun, C. (2002). The class consciousness of frequent travellers: Towards a critique of actually existing cosmopolitanism. In S. Vertovec \& R. Cohen (Eds.), Conceiving cosmopolitanism. theory, context, and practice (pp. 86-109). Oxford: Oxford University Press.

Corm, G. (1998). Le Liban dans les filets séculaires de la glo balisation. Les Cahiers de l'Orient, $52,15-27$.

Dahlgren, S. (2010). Contesting realities: The public sphere and morality in southern Yemen. Syracuse: Syracuse University Press.

de Koning, A. (2009). Global dreams: Class, gender, and public space in cosmopolitan Cairo. Cairo: American University in Cairo Press.

Driessen, H. (2005). Mediterranean port cities: Cosmopolitanism reconsidered. History and Anthropology, 16(1), 137.

Eldem, E. (2013). Istanbul as a cosmopolitan city. Myths and realities. In A. Quayson \& G. Daswani (Eds.), A companion to diaspora and transnationalism (pp. 212-230). Chichester: Wiley-Blackwell.

Escallier, R. (2003). Le cosmopolitisme méditerranéen: ré-flexions et interrogations. Cahiers de la Méditerranée, 67/2003 (online).

Friedman, J., \& Rabau, S. (2000). Des racines et (dé)routes. Tropes pour trekkers. L'Homme, 156, $187-206$.

Fuccaro, N. (2009). Histories of City and state in the Persian Gulf. In Manama since 1800. Cambridge: Cambridge University.

Gardner, A. (2010). City of strangers: Gulf migration and the Indian community in Bahrain. Ithaca: Cornell University Press.

Gavin, R. J. (1975). Aden under British rule. 1839-1967. London: Hurst.

Gekas, A. (Sakis). (2009). Class and cosmopolitanism: The historiographical fortunes of merchants in eastern Mediterranean ports. Mediterranean Historical Review, 24(2), 95-114.

Hanley, W. (2008). Grieving cosmopolitanism in Middle East studies. History Compass, 6(5), $1346-1367$.

Ilbert, R. (1991). De Beyrouth à Alger, la fin d'un ordre urbain. Vingtième Siècle, 32, 15-32.

Ilbert, R. (1992). Alexandrie cosmopolite. In P. Dumont \& F. Georgeon (Eds.), Villes ottomanes à la fin de l'empire (pp. 171-185). Paris: L'Harmattan.

Lackner, H. (1985). P. D. R. Yemen: Outpost of socialist development in Arabia. London: Ithaca Press.

Lefebvre, H. (2000). La production de l'espace. Paris: Anthropos. 
Lefebvre, H., \& Régulier, C. (1986). Essai de rythmanalyse des villes méditerranéennes. Peuples méditerranéens, 37, 5-16.

Lofland, L. H. (1973). A world of strangers: Order and action in urban public space. Prospect Heights: Waveland Press.

Mansel, P. (2010). Levant: Splendour and catastrophe on the Mediterranean. London: John Murray.

Mermier, F. (2001). Yaman -Ethnology and social structure of the Yemeni highlands. Encyclopaedia of Islam, 9, 276-277.

Mermier, F. (2011). Souk et citadinité dans le monde arabe. In F. Mermier \& M. Peraldi (Eds.), Mondes et places du marché en Méditerranée. Formes sociales et spatiales de l'échange (pp. 19-42). Paris: Karthala/CJB/IFPO.

Métral, J. (1995). Ordres urbains et cosmopolitismes en Méditerranée orientale. In I. Joseph (Ed.), Prendre place. Espace public et culture dramatique (pp. 261-271). Paris: Editions Recherche/ Plan Urbain, Association des Amis de Pontigny-Cerisy.

Peterson, M. A. (2011). Connected in Cairo: Growing up cosmopolitan in the modern Middle East. Bloomington: Indiana University Press.

Singerman, D., \& Amar, P. (2006). Contesting myths, critiquing cosmopolitanism, and creating the New Cairo School of Urban studies. In D. Singerman \& P. Amar (Eds.), Cairo Cosmopolitan. politics, culture, and urban space in the new globalized Middle East (pp. 3-43). Cairo: American University in Cairo Press.

Stookey, R. (1982). South Yemen: A Marxist republic in Yemen. London: Westview Press.

Trivellato, F. (2009). The familiarity of strangers: The Sephardic diaspora, Livorno, and crosscultural trade in the early modern period. New Haven: Yale University Press.

Vignal, L., \& Denis, E. (2006). Cairo as regional/Global economic capital. In D. Singerman \& P. Amar (Eds.), Cairo cosmopolitan: Politics, culture, and urban space in the new globalized Middle East (pp. 99-151). Cairo: American University in Cairo Press.

Werbner, P. (2008). The cosmopolitan encounter: Social anthropology and the kindness of strangers. In P. Werbner (Ed.), Anthropology and the new cosmopolitanism (pp. 47-68). Oxford: Berg. Zayn, A. (2015). Steamer point. Beirut/Cairo: Dar al-Tanwir.

Zubaida, S. (1999). Cosmopolitanism and the Middle East. In R. Meijer (Ed.), Cosmopolitanism, identity and authenticity in the Middle East (pp. 15-33). Richmond: Curzon.

Open Access This chapter is licensed under the terms of the Creative Commons Attribution 4.0 International License (http://creativecommons.org/licenses/by/4.0/), which permits use, sharing, adaptation, distribution and reproduction in any medium or format, as long as you give appropriate credit to the original author(s) and the source, provide a link to the Creative Commons license and indicate if changes were made.

The images or other third party material in this chapter are included in the chapter's Creative Commons license, unless indicated otherwise in a credit line to the material. If material is not included in the chapter's Creative Commons license and your intended use is not permitted by statutory regulation or exceeds the permitted use, you will need to obtain permission directly from the copyright holder.

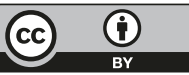

